\title{
Successful development of novel monoclonal antibodies against HTLV-1 bZIP factor and their applications in studying the pathogenesis of $\mathrm{HAM} / \mathrm{TSP}$
}

\author{
Mineki Saito ${ }^{1 *}$, Reiko Tanaka ${ }^{1}$, Akira Kodama ${ }^{1}$, Toshio Matsuzaki ${ }^{2}$, Masahito Suehara ${ }^{3}$, Yuetsu Tanaka ${ }^{1}$ \\ From 15th International Conference on Human Retroviruses: HTLV and Related Viruses \\ Leuven and Gembloux, Belgium. 5-8 June 2011
}

\section{Background}

A recent report has indicated that transgenic expression of HTLV-1 bZIP factor (HBZ) in CD4+ T cells induced Tcell lymphomas and systemic inflammation in mice. However, there is limited information on in vivo expression of HBZ in HTLV-1 infected individuals especially HAM/TSP.

\section{Methods}

We have generated rat and human monoclonal antibodies against HBZ by hybridoma methodology and a phage display system, and developed the ELISA system for the detection of HBZ protein and anti-HBZ antibodies. Using these reagents, we analyzed the expression of HBZ protein in plasma and peripheral blood mononuclear cells (PBMCs) of HTLV-1 infected individuals as well as HTLV-1 infected cell lines. Then the results were compared with the real time PCR data.

\section{Results}

Although we successfully detected HBZ protein in an enforced overexpressed cells and HTLV-1 infected cell lines by flow cytometry, ELISA, immunofluorescence and immunoblotting, we could not detect HBZ protein or anti-HBZ antibodies in HAM/TSP patients and asymptomatic carrires (ACs) by our system. In contrast, HBZ mRNA was significantly elevated in HAM/TSP patients than ACs. Especially, rapidly progressive HAM/ TSP patients showed extremely high expression of HBZ mRNA but not tax mRNA in their PBMCs.

\footnotetext{
* Correspondence: mineki@med.u-ryukyu.ac.jp

'Department of Immunology, University of the Ryukyus, Okinawa, 903-0215, Japan

Full list of author information is available at the end of the article
}

\section{Conclusions}

These findings suggest that although expression of HBZ protein was suppressed in vivo in HAM/TSP patients and ACs, high expression of HBZ mRNA is closely associated with the pathogenesis of HAM/TSP.

\section{Author details}

'Department of Immunology, University of the Ryukyus, Okinawa, 903-0215, Japan. ${ }^{2}$ Department of Neurology, Ohkatsu Hospital, Kagoshima, 890-0067, Japan. ${ }^{3}$ Department of Neurology, National Okinawa Hospital, Okinawa, 9012214, Japan

Published: 6 June 2011

doi:10.1186/1742-4690-8-S1-A244

Cite this article as: Saito et al:: Successful development of novel monoclonal antibodies against HTLV-1 bZIP factor and their applications in studying the pathogenesis of HAM/TSP. Retrovirology 2011 8(Suppl 1):A244.

Submit your next manuscript to BioMed Central and take full advantage of:

- Convenient online submission

- Thorough peer review

- No space constraints or color figure charges

- Immediate publication on acceptance

- Inclusion in PubMed, CAS, Scopus and Google Scholar

- Research which is freely available for redistribution

Submit your manuscript at www.biomedcentral.com/submit

\section{Biomed Central}

(c) 2011 Saito et al; licensee BioMed Central Ltd. This is an open access article distributed under the terms of the Creative Commons Attribution License (http://creativecommons.org/licenses/by/2.0), which permits unrestricted use, distribution, and reproduction in any medium, provided the original work is properly cited. 